\title{
Resolving and Parameterising the Ocean Mesoscale in Earth System Models
}

\author{
Helene T. Hewitt ${ }^{1}$ (D) $\cdot$ Malcolm Roberts ${ }^{1} \cdot$ Pierre Mathiot $^{1} \cdot$ Arne Biastoch $^{2} \cdot$ Ed Blockley $^{1} \cdot$ Eric P. Chassignet $^{3}$. \\ Baylor Fox-Kemper ${ }^{4}$. Pat Hyder ${ }^{1}$. David P. Marshall ${ }^{5}$. Ekaterina Popova ${ }^{6}$. Anne-Marie Treguier ${ }^{7}$. Laure Zanna ${ }^{8}$. \\ Andrew Yool ${ }^{6}$. Yongqiang Yu ${ }^{9,10} \cdot$ Rebecca Beadling $^{11}$ - Mike Bell ${ }^{1}$. Till Kuhlbrodt ${ }^{12}$. Thomas Arsouze ${ }^{13}$. \\ Alessio Bellucci $^{14}$. Fred Castruccio ${ }^{15,16} \cdot$ Bolan Gan $^{17,16} \cdot$ Dian Putrasahan $^{18} \cdot$ Christopher D. Roberts $^{19}$. \\ Luke Van Roekel $^{20}$ • Qiuying Zhang ${ }^{21,16}$
}

Accepted: 14 September 2020 / Published online: 7 October 2020

(C) The Author(s) 2020, corrected publication 2020

\begin{abstract}
Purpose of Review Assessment of the impact of ocean resolution in Earth System models on the mean state, variability, and future projections and discussion of prospects for improved parameterisations to represent the ocean mesoscale.

Recent Findings The majority of centres participating in CMIP6 employ ocean components with resolutions of about 1 degree in their full Earth System models (eddy-parameterising models). In contrast, there are also models submitted to CMIP6 (both DECK and HighResMIP) that employ ocean components of approximately $1 / 4$ degree and 1/10 degree (eddy-present and eddy-rich models). Evidence to date suggests that whether the ocean mesoscale is explicitly represented or parameterised affects not only the mean state of the ocean but also the climate variability and the future climate response, particularly in terms of the Atlantic meridional overturning circulation (AMOC) and the Southern Ocean. Recent developments in scale-aware parameterisations of the mesoscale are being developed and will be included in future Earth System models.

Summary Although the choice of ocean resolution in Earth System models will always be limited by computational considerations, for the foreseeable future, this choice is likely to affect projections of climate variability and change as well as other aspects of the Earth System. Future Earth System models will be able to choose increased ocean resolution and/or improved parameterisation of processes to capture physical processes with greater fidelity.
\end{abstract}

Keywords Ocean models $\cdot$ Resolution $\cdot$ Parameterisation $\cdot$ Mesoscale $\cdot$ Submesoscale

\section{Introduction}

The Earth System is inherently coupled, but ocean heat uptake determines the Earth's energy budget [1] and global sea level rise [2]. The ocean has a key role linking to other parts of the Earth System, e.g. sea surface temperatures (SSTs) affect atmospheric circulation and precipitation [3], ocean circulation

This article is part of the Topical Collection on Advances and Future Directions in Earth System Modelling

Helene T. Hewitt

helene.hewitt@metoffice.gov.uk

Extended author information available on the last page of the article
[4] and biogeochemistry [5] determine the flux of carbon between the oceanic and atmospheric reservoirs, and upper ocean temperatures and circulation influence sea ice properties and dynamics, while sea ice also feeds back onto the ocean circulation via insulation and freshwater input. Global and regional sea levels are strongly influenced by highlatitude ocean processes associated with the basal melting of Antarctic ice shelves [6] and ocean-driven melting of the Greenland ice sheet [7].

Since the first review in 2000 [8], the ocean components of Earth System models (ESMs) have evolved considerably following the different phases of coupled model intercomparison projects, CMIP3 to CMIP5, and most recently CMIP6 [9]. Conservation of heat and salt, exact computation of sea level, and the improvement of water mass properties have been the 
main objectives that have led modelling groups to abandon rigid-lid formulations and time-invariant vertical grids, and to develop higher-order advection schemes. Community modelling platforms such as NEMO [10], MOM (https://momocean.github.io/), or POP [11] have been extended to offer a larger choice of grids, numerical schemes, and parameterisations. Two new ocean models with flexible grids have been introduced in CMIP6: FESOM [12] and MPAS [13], and although CMIP6 models generally use quasi-geopotential grids (' $z$-coordinates'), one model has terrain-following coordinates (INM-CM5) [14] and two models use Lagrangian hybrid coordinates following isopycnals in the interior: MOM6 [15] and Nor-ESM [16].

This paper reviews the state of knowledge of the importance of ocean resolution drawing on recent results from CMIP6 models (including HighResMIP [17]) and building on previous reviews [18-20] to address to what extent ocean resolution introduces uncertainty into climate variability and projections of future climate. Although the emphasis of this review is on multi-decadal climate timescales, many of our conclusions also have relevance for initialised predictions with coupled forecast models $[18,21]$. The 'Resolution in Ocean Components of CMIP6 Earth System Models' section reviews the current status of resolution in ocean components of CMIP6 Earth System models. The 'Impact of Ocean Resolution on Mean State, Variability, and Future Projections' section reviews the impact of ocean resolution on the mean state, variability, and future projections of key metrics. The 'Links to Other Aspects of the Earth System' section reviews linkages between ocean resolution and other components of the Earth System reviewed in this issue. The 'Advances in Parameterising the Mesoscale for Future Earth System Models' section discusses advances in parameterisation of the mesoscale which are applicable for future developments of ESMs. The 'Summary' section summarises the review.

\section{Resolution in Ocean Components of CMIP6 Earth System Models}

Ocean models for climate, as atmospheric models, evolve constantly towards higher resolution. This is driven, in part, by the need to better represent strong western boundary currents such as the Agulhas Current, the Gulf Stream, or the Kuroshio, which play a key role in transporting heat from the equator to the poles. These currents have a typical width of $100 \mathrm{~km}$, which means that grid meshes of 10-20 km are necessary to represent their dynamics. Improved horizontal resolution also allows for a better simulation of key straits such as the Gibraltar or Denmark Strait and their role in the inter-basin exchanges. Estimating grid resolution as the square root of the surface area of the Earth divided by the total number of grid points, the average resolution was $133 \mathrm{~km}$ for CMIP3, $87 \mathrm{~km}$ for CMIP5, and $58 \mathrm{~km}$ for CMIP6 (giving a timescale for doubling of ocean resolution in models of approximately 10 years [22]). The decrease is driven both by the refinement of the ESM grids and by the participation of more ocean general circulation models with very fine grids, in the 10-40-km range. This move has been strongly encouraged by HighResMIP [17], a protocol especially defined for highresolution models. The OMIP, Ocean Model Intercomparison Project [23, 24], is also designed to help evaluate the impact of resolution on ocean simulations [25].

ESM development has to prioritise between allocating computational resources either to enhance resolution or to increase complexity (as well as considering the length of the spin-up and ensemble size). Although ESMs in CMIP6 have evolved in terms of their complexity [26-29], it is clear that most have retained ocean resolutions which require parameterisation of mesoscale eddies [30] as they fail to resolve the Rossby radius $[17,30]$. The Rossby radius length scale is key to the representation of mesoscale eddies, boundary currents and fronts, and topographic flows $[15,18]$. The length scales of the fastest-growing modes in the ocean have been shown to vary less strongly with latitude than suggested by the Rossby radius [31] with larger length scales observed in eastward-flowing currents. Nevertheless, taking the Rossby radius as a guide, three regimes of models [32] can be defined: eddy-parameterising (ocean resolution of $\mathrm{O}(50-100 \mathrm{~km})$ and the current status for the majority of ESMs which mostly employ the Gent-McWilliams (GM) [33] parameterisation of mesoscale eddies), eddy-present (ocean resolution of $\mathrm{O}$ $(25 \mathrm{~km})$ with HighResMIP experiments at this resolution and some models of this resolution in the CMIP6 DECK experiment), and eddy-rich (ocean resolution of $\mathrm{O}(10 \mathrm{~km})$ with some HighResMIP experiments at this resolution but noting that even models at this resolution do not resolve mesoscale eddies poleward of approximately $50^{\circ}$ ). Given that a major constraint for running at higher resolutions is the computational cost, some models also exploit variable resolution or nested high-resolution grids [34, 35].

A particular issue for models in the eddy-present regime is that the Rossby radius is resolved at lower latitudes but not at higher latitudes (or in shallow/shelf regions). This resolution is often referred to as the 'grey zone' when the Rossby radius is only marginally resolved and there is a question as to whether a parameterisation of mesoscale eddies should be included at this resolution. In CMIP6 models, the approach at the eddypresent resolution varies between models. For example, at $1 / 4^{\circ}$ resolution, different model families make different choices about the use of GM [36, 37]. This is also an issue in eddy-rich models but at higher latitudes than in eddypresent models.

At even smaller spatial (and higher temporal) scales (100 m-10 km, hours to days), the parameterisation of 
submesoscale phenomena is also starting to be addressed in ESMs; the Fox-Kemper [38, 39] parameterisation of ocean surface boundary layer restratification by mixed layer instabilities has been followed by variants with different assumptions or for alternative submesoscale instabilities [40, 41] and implementations in ESMs [38, 42]. Submesoscale eddies need much higher resolution to resolve the smaller deformation radius of the mixed layer [43], but as demonstrated for the Agulhas system, there is evidence that the explicit simulation of submesoscale processes enhances the mesoscales [44]. Resolving submesoscale eddies is a target for climate simulations in future decades.

\section{Impact of Ocean Resolution on Mean State, Variability and Future Projections}

\section{Western Boundary Currents}

In typical CMIP5/6 models, with resolutions in the eddyparameterising regime, simulated western boundary currents (WBCs) are much weaker and wider than observed, and the most significant biases in surface temperature are usually associated with incorrect presentation of WBCs in coupled models. Eddy-present models lead to a significant improvement in the representation of the WBCs as the ocean model becomes less diffusive/viscous with enhanced resolution, generally improving the simulation of the strength and position of WBCs such as the Gulf Stream, Kuroshio Current, and Agulhas Current [17, 25, 45-50]. For example, eddy-present and eddy-rich models show much better representation of the North Pacific subtropical gyre currents than eddyparameterising models $[18,19,25,32,49]$ where the Kuroshio separation and extension are often located at least $300-400 \mathrm{~km}$ further northward than observations. Despite general improvements in WBC representation due to model resolution, there remains dependence on the models' numerics [51].

Mesoscale eddy activity is observed to be high in WBC regions, and the magnitude of eddy kinetic energy in these regions is strongly related to model resolution. Eddy tracking [52] demonstrates that an increasing number of eddies are simulated in WBC regions as resolution increases to the eddy-present and eddy-rich regimes. The magnitude of eddy kinetic energy in WBC regions is found to be strongly related to model resolution $[37,50,51]$. As mesoscale eddies potentially play a role in determining the strength of the gyre circulations and their low-frequency variability [53, 54], it is expected that decadal variability and sensitivity of the circulation to changes in wind stress will differ between eddy-rich and eddy-parameterised models.

In the case of the Agulhas Current where the leakage directly influences the hydrography in the Atlantic $[55,56]$, eddy-present and eddy-parameterising models overestimate the leakage by a factor of 2-3 [57]. There is also an indication that eddy-rich resolution is important for the determination of the relative role of warm and saline Agulhas leakage versus cold and fresh waters entering the Atlantic through the Drake Passage [58].

Some stand-alone high-resolution oceanic models tend to overestimate mesoscale eddies and underestimate the strength of WBCs, which is partly attributed to a lack of mesoscale airsea interaction $[59,60]$ and partly attributed to incorrect representation of submesoscale motions in these models [61]. Eddy-present/rich coupled ocean-atmosphere models have substantially weaker eddies than eddy-present/rich oceanonly models without the surface current-wind stress interaction process because both the wind work and eddy-induced linear Ekman pumping dampen eddy kinetic energy when the surface currents are involved in the bulk formula [60, 62]. The Agulhas eddies' pathway is also quite sensitive to the wind stress ('relative' versus 'absolute', depending on whether the ocean velocity is considered for the wind stress calculation) in forced simulations [51].

Beyond the eddy-rich resolution, further improvements (i.e. penetration) are found when the resolution is refined to $\sim 1 \mathrm{~km}[50,63,64]$ and when a net release of available potential energy associated with mixed layer instability is responsible for the emergence of submesoscale eddies in wintertime [63]. At that resolution, submesoscale turbulence affects the kinetic energy exchanges and provides an inverse cascade of energy to larger scales [44, 64]. These extremely highresolution experiments can be used in conjunction with machine learning techniques (e.g. deep learning) to design ocean eddy parameterisation for implementation in the coarser ocean models [65, 66] (see the 'Advances in Parameterising the Mesoscale for Future Earth System Models' section for further discussion).

\section{Atlantic Meridional Overturning Circulation}

The Atlantic meridional overturning circulation (AMOC) transports warm, buoyant water polewards in the Atlantic. Cooling at high latitudes, coupled with the relatively high salinity of the Atlantic, means that fluid parcels become sufficiently dense to convect and return equatorward at depth. This circulation drives a northward heat transport of about 1.2 PW at $26.5^{\circ} \mathrm{N}$. Observations from the RAPID-MOCHA array since 2004 [67] show variability on all timescales with interannual variability typically of the order several Sv, with a larger temporary decrease of $4.7 \mathrm{~Sv}$ over 2009/2010 [68]. Most CMIP5 models [69] underestimate interannual variability and rarely if ever simulate such a large annual drop, though their daily variability can agree with observations [70, 71]. More recent eddy-present forced-ocean simulations [72] better capture the magnitude of interannual variability, 
suggesting that either ocean model resolution or atmospheric forcing/resolution is key. In CMIP6 HighResMIP and OMIP simulations (see Fig. 1a, b), the AMOC transport more often than not becomes stronger at higher ocean resolution [20], and in coupled models, this tends to be driven by enhanced convection in the Labrador Sea [73, 75]. For both CMIP5 models [76] and CMIP6 HighResMIP [73], there tend to be too deep mixed layers in the Labrador Sea in order for the AMOC strength to be comparable with observations (noting that this is particularly true in NEMO models, suggesting that the model structure as well as resolution may be a factor). When projecting future climate, this convection tends to reduce more quickly than that in the Nordic Seas [73], which means that the higher-resolution models have a stronger AMOC decline in the future. The effect of convection changes in the Nordic Seas is linked to the AMOC via the overflows.
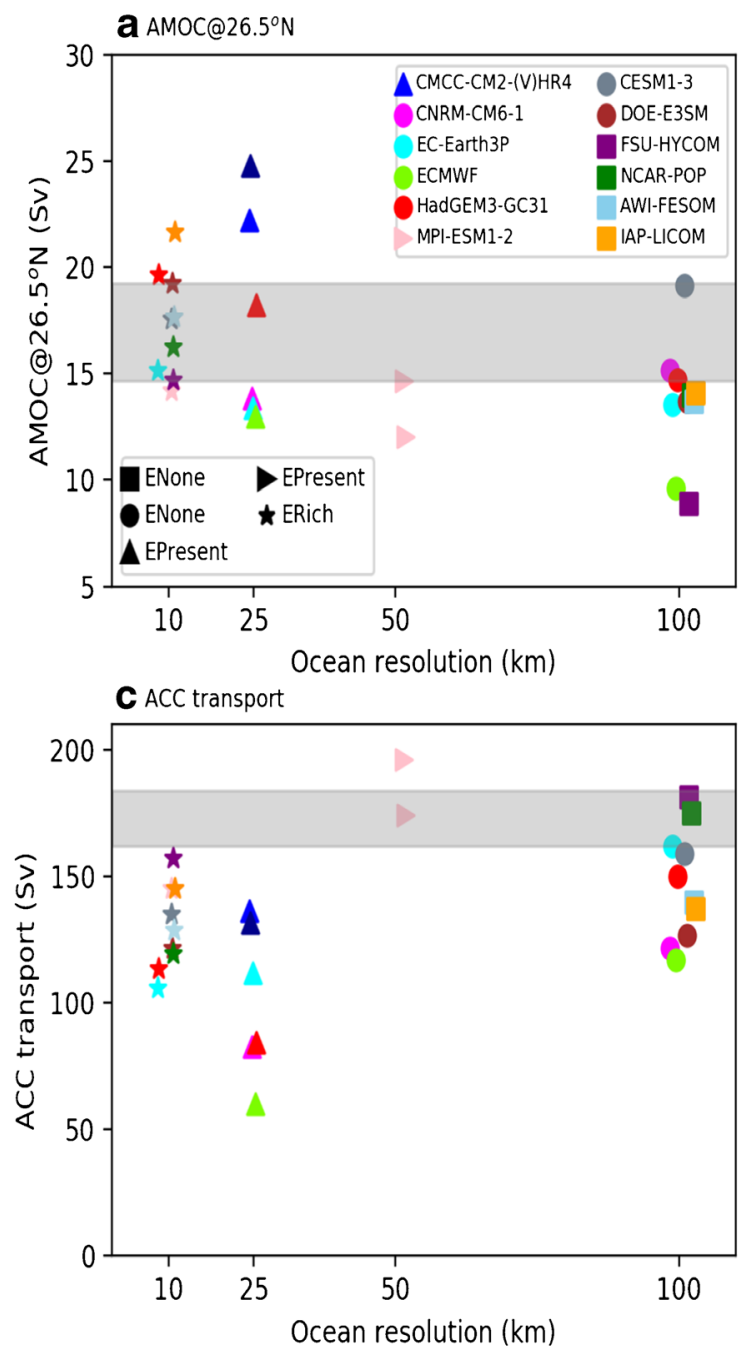

Fig. 1 Comparison of multi-model large-scale ocean metrics with observations. a AMOC and b northward heat transport (NHT) in the Atlantic at $26.5^{\circ} \mathrm{N}$. c ACC transport (Sv). d An illustration of the impact of ocean model resolution on the ACC-AMOC simulation. Model simulations are from CMIP6 OMIP experiments [25] and from
The overflows of dense waters over the GreenlandScotland Ridge (GSR), through Denmark Strait and the Iceland-Faroe channel, drive two-thirds of the AMOC [77]. Their dynamics are governed by small-scale physical processes such as ageostrophic flows in the bottom boundary layer, instabilities, and entrainment that are difficult to represent in numerical models $[78,79]$, especially at low resolution [80]. The relationship between the strength of the overflows and the AMOC is complex in models, because the AMOC depends on a number of processes [81]. Rather than the strength of the AMOC, its vertical structure critically depends on the depth to which overflows sink [80]. Also, the overflows tend to be stable over decadal timescales, which results in the AMOC decadal and subdecadal variabilities being mostly dependent on the water mass formation in the subpolar gyre [81]. On the other hand, the influence of the overflows is strong on the
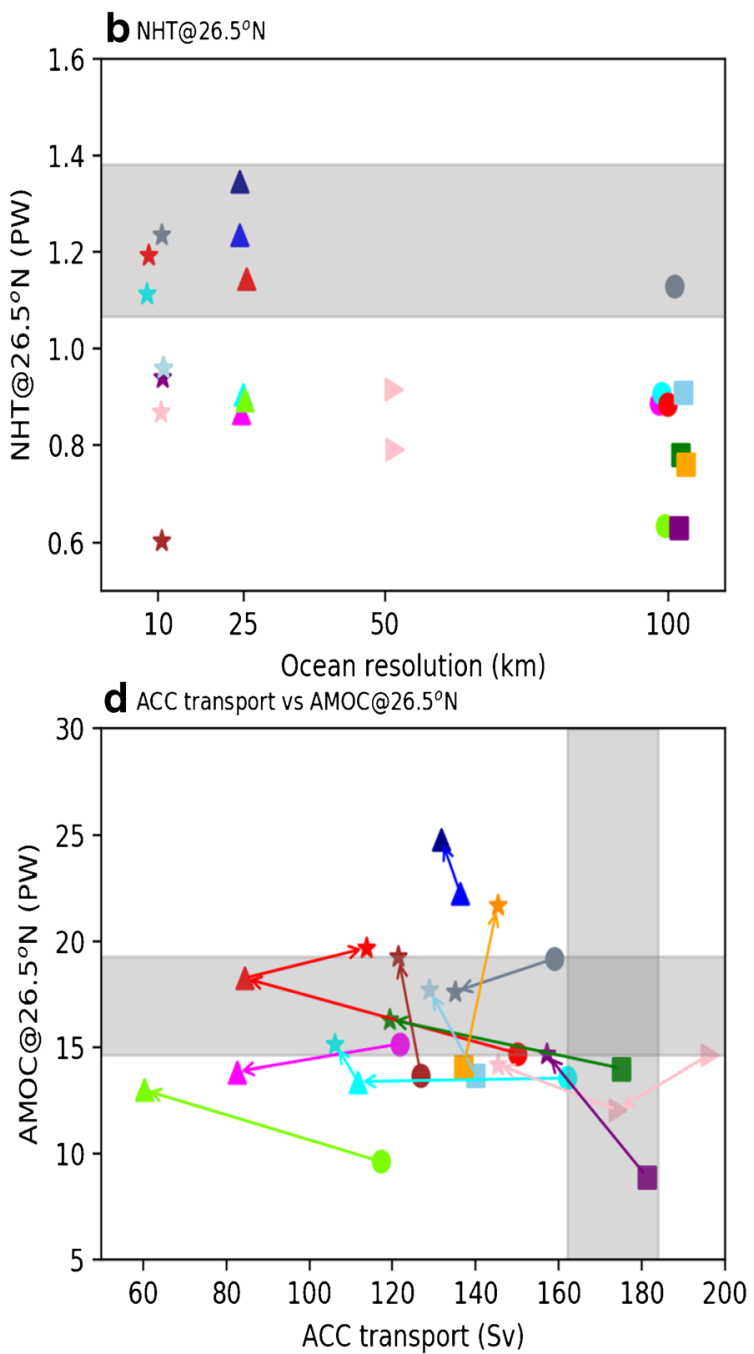

CMIP6 HighResMIP control-1950 experiments [73] (plus additional data not yet archived, see 'Model Data' for details). AMOC/NHT observations $[67,68]$ are shaded with the annual mean range between 2004 and 2017. ACC observations from the cDrake array [74] are shaded indicating 173 $\pm 11 \mathrm{~Sv}$ 
water mass properties and on the deep stratification of the subpolar gyre, which in turn influences the depth of wintertime convection [82].

The choice of vertical grid is expected to influence the representation of dense overflows. CMIP6 models generally employ $z$-coordinates (with variants such as time dependence of thickness to follow the motions of the free surface $\left(z^{*}\right)$ and partial cell topography in the deepest layer), but terrainfollowing coordinates and Lagrangian hybrid coordinates are also used [14-16]. Hybrid coordinates are designed to avoid spurious diapycnal mixing and better represent the entrainment downstream of the overflows. However, even in these models, the degree of improvement for the depth of the overflows and the AMOC vertical structure depends on the horizontal resolution and other model choices $[15,16,81]$. In all vertical coordinate systems, moving to higher horizontal resolution improves the representation of the overflows [16, 83] and their influence on AMOC, both because the bathymetry is more realistic and because the bathymetry is more realistic and because the dynamics of the deep boundary currents is better represented [84]. Higher vertical resolution, however, can degrade the solution in $z$-coordinate models, because it can increase spurious diapycnal mixing in downslope flows [83]. A complete analysis of overflows in HighResMIP ocean models is not yet available for a full assessment of the progress made relative to CMIP5.

\section{Antarctic Circumpolar Current and Associated Southern Ocean Dynamics}

Different aspects of the regional dynamics in the Southern Ocean are closely dynamically linked including the Antarctic circumpolar current (ACC), the Southern hemisphere upper and lower MOC cells, temperature and salinity structure and associated meridional gradients, and sea ice processes [85]. For example, the Southern Ocean mean state and its response to expected future changes in wind stress forcing, including the upper cell of its overturning circulation which influences heat and carbon uptake and isopycnal slopes that drive the ACC, result from a subtle balance between larger opposing wind-forced and eddy-driven cells [86]. Perhaps in consequence, representation of all of these ocean processes shows considerable sensitivities to ocean model resolution and configuration, even including fairly subtle changes to closure schemes which represent the impacts of sub-grid-scale processes [87, 88].

The simulation of the ACC is sensitive to model resolution in both forced and coupled simulations (Fig. 1c). Relative to observations from the cDrake array [74], models tend to fall on the lower end of observational uncertainty or underestimate the net ACC volume transport [85]. Models in the eddyparameterised or eddy-rich regime perform better than those in the eddy-present regime which are particularly sensitive to the choice of uncertain grid-scale closures as seen in forcedocean experiments [15, 36, 37].

The few CMIP6 models in the eddy-present regime provide a much more realistic representation of the frontal jets of the ACC [85] in contrast to the majority of models which have lower resolution and completely fail to represent any distinct fronts. These higher-resolution models, however, also show distinct counter flows (presumably linked to stationary eddies in Drake Passage) in multi-decadal means which are not evident in the observational means over similar periods (although they may be evident in sections from individual cruises). Increased model resolution allows for greater topographic detail to be resolved leading to improved topographic control of the ACC. In CMIP5, a weaker relationship between the ACC strength and position with westerly winds compared with CMIP3 was attributed to this control [89]. Further work is required to investigate this in CMIP6 and eddy-rich models.

There is much ongoing effort to better understand the strong dependence of the ACC on ocean resolution. Preliminary unpublished findings suggest that in Hadley Centre models, ACC transports using ocean resolution of $1 / 4^{\circ}$ are rather sensitive to subtle changes in the configuration of grid-scale closures, such as viscosity, the use of weak GM, the use of localised partial slip at topographic boundaries, and even changes to bed stress. Analyses of perturbed parameter ensemble with a $1 / 4^{\circ}$ ocean model [90], in which only atmospheric parameters are perturbed, also suggest that there may be a link between large-scale Southern Ocean SST biases; sea ice concentrations and associated meridional freshwater transports; near coastal salinity biases that drive a strong westward counter flow around the continental margin through the Drake Passage, weakening the total ACC transport; and Weddell Sea sea ice and salinity biases that cause a spurious polynya to form causing deep convection and large changes to Antarctic bottom water properties.

Several other studies have also noted multi-decadal temporal variations in ACC transports, of 10 to $30 \mathrm{~Sv}$, linked to the occurrence of unrealistic large open-ocean polynya events, in both the Ross and Weddell Sea, which alter the density structure of the Southern Ocean through intense spurious openocean convection [85]. In $1 / 4^{\circ}$ and $1 / 2^{\circ}$ GFDL models [91, 92], super-polynyas in the Ross Sea have been shown to drive large centennial-scale variability in the Southern Hemisphere climate. These events are found in both the eddyparameterising models used in CMIP6 and higher-resolution models [91-93]. Whether there is a resolution dependence on their frequency and characteristics is a topic of future study. With the exception of the 1974-1976 [94, 95] and 2016-2017 [96] polynya events observed in the Weddell Sea, there is no observational evidence to support the frequent open-ocean polynyas and associated intense open-ocean convection that are found in model simulations. Furthermore, there is no observational evidence of large open-ocean polynyas in the Ross 
Sea, where these events are commonly simulated in models. For these reasons, the dynamics associated with these events is a topic of focus as a means for improving simulations in future model development.

Substantial changes to the strength and latitudinal location of the westerly winds over the Southern Ocean have occurred and are expected to continue through a combination of ozone and greenhouse gas climate forcing. Future wind-driven changes in the strength of the ACC under climate change, and associated changes to the upper cell of the Southern Ocean MOC, may also depend strongly on ocean resolution. Idealised equilibrated ocean-only experiments suggest that at equilibrium in eddy-rich models, changes to the Ekmandriven overturning cell due to increased wind stress forcing are opposed by subsequent changes to the counter-rotating eddy-driven cell caused by increases in eddy kinetic energy [97] although the transient adjustment could be different to the equilibrium. This considerably reduces the sensitivity to changes in wind stress magnitude of both the upper cell of the Southern Ocean overturning circulation and, through its impact on isopycnal slopes, the strength of the ACC, processes termed 'eddy compensation' and 'eddy saturation', respectively. Evidence suggests that although the eddy response is not correctly represented in eddy-parameterising models, partial eddy compensation and eddy saturation are obtained in some models in which GM is allowed to vary spatially and temporally [87] and even to some extent with constant GM [98].

One interesting finding across the CMIP6 and associated HighResMIP ensemble is that many models with a (good) high ACC transport often have a (poor) low AMOC strength, and vice versa (Fig. 1d, b). This requires further investigation, but such a relationship could arise through either opposing responses to common grid-scale numerics (for example, more damping could result in weaker Gulf Stream transports but stronger ACC transports) or opposing dynamical links (for example, the Gnanadesikan model [99] suggests that a stronger AMOC should act to reduce the density gradients across the ACC, weakening its transport).

\section{Sea Surface Temperature}

SST is a key metric since it is the primary way that the ocean impacts the atmosphere and vice versa. The large-scale pattern of SST in ESMs demonstrates errors that are broadly similar across a range of models with cooling in the North Pacific, warming in the Southern Ocean, warming in the Eastern Boundary Upwelling zones, and a patch of very cold water ('blue spot') in the North Atlantic [26, 28, 29, 91, 100]. In many models, the magnitude of the Southern Ocean warming has been improved significantly through focussed effort largely to improve cloud biases [101]. Enhancing ocean resolution often leads to a reduction in the North Atlantic cold bias [102,
103] associated with the improvement in the position of the North Atlantic current, but forced-ocean experiments suggest that this is not always the case $[15,25,36,37]$. In coupled models with eddy-present or eddy-rich resolutions $[35,49$, 104, 105], there are typical but not uniform improvements in the Atlantic in both the tropics (both cold bias and zonal gradient) and mid-latitudes, the cold tongue in the tropical Pacific and the warm biases in the upwelling/stratocumulus regions off the western coasts of South America and Southern Africa, while the Southern Ocean surface warm bias tends to be increased.

Key impacts of parameterisations of submesoscale restratification in ESMs are shallower mixed layers particularly in wintertime, affecting air-sea fluxes, energy transfers, sea ice, and biogeochemistry [38, 106-108]. Without further alteration to other aspects of the ESM, most implementations see improved extratropical winter hemisphere mixed layers but degraded tropical and austral summer Southern Ocean biases [38, 42]. However, the use of the submesoscale parameterisation is not a good predictor as to whether models will have a good representation of the mixed layer [75, 109], which is perhaps unsurprising given the level of disagreement between models of boundary layer mixing [110].

\section{Heat Uptake}

Ocean and coupled models initialised from rest with climatological temperature and salinity generally gain or lose heat as they approach a quasi-equilibrium. The underlying drifts in temperature can be affected by both horizontal resolution $[32,104,111]$ and the choice of vertical coordinate [15]. Models with horizontal resolutions in the eddy-present regime often have deep biases $[32,104,111]$ that are worse than biases in models in either the eddy-parameterising or eddyrich regime which may be linked to surface biases [101] propagated to the subsurface [111]. Excess interior mixing due to numerics [112] can be alleviated by moving from a depth coordinate to an isopycnal coordinate in the interior of the ocean [15], reducing heat uptake in the GFDL model by a factor of approximately 500 from $1 \mathrm{~W} / \mathrm{m}^{2}$ when a hybrid depth-isopycnal vertical coordinate was used.

Work with simplified models $[113,114]$ suggests that heat uptake due to anthropogenic forcing will occur in the ventilated thermocline on the timescale of a few decades and in the deeper ocean on a longer timescale associated with changes in the AMOC and that insufficiently resolved eddies in the eddypresent regime could lead to reduced ocean heat uptake at depth. In idealised experiments, the Southern Ocean plays a particularly important role in global ocean heat (and anthropogenic carbon) uptake [114] (see also the 'Antarctic Circumpolar Current and Associated Southern Ocean Dynamics' section), and more realistic sensitivity experiments have suggested that Southern Ocean heat uptake is sensitive to 
horizontal resolution when moving from the eddyparameterising to the eddy-present regime [115], to the near surface vertical resolution [116], and, in eddy-parameterising models, to the magnitude of the thickness diffusion parameter [117].

There are currently insufficient results from eddy-rich simulations to assess the impact of this resolution on projections of future ocean heat uptake. Projections of ocean heat uptake from eddy-rich models are likely to be limited by the length of the spin-up, as the magnitude of the underlying drift is likely to affect stratification and rates of ocean heat uptake [118]. A long spin-up which would be required for smaller drifts [119] is currently too expensive for eddy-rich models, but in the next decade, as DECK simulations are extended to include eddyrich models, this will be an area for future research.

The uptake of anthropogenic $\mathrm{CO}_{2}$ over the historical period and into the twenty-first century is heavily influenced by the background ocean transport, which includes large-scale advection and eddy transport [120]. Like heat, a large fraction of the anthropogenic $\mathrm{CO}_{2}$ taken up by the oceans occurs in the Southern Ocean, and we can expect that the storage might be sensitive to horizontal resolution.

\section{Links to Other Aspects of the Earth System}

\section{Sea Ice}

Sea ice is comprised of floes and resembles a generally moving jumble of irregular, often interlocked, pieces of ice that vary in size from a few metres up to tens of kilometres. Crucially, sea ice is not a turbulent fluid, and so we would not expect performance to respond to grid resolution changes in the same way as in the ocean or atmosphere [121, 122].

Sea ice is highly non-Gaussian in nature and exhibits considerable heterogeneity in both time and space. To account for this, sea ice evolution in contemporary climate models is targeted at scales of $\sim 100 \mathrm{~km}$ over periods of days to months and expressed in terms of local balances of conserved quantities such as mass and heat, with unresolved, small-scale processes handled using numerous parameterisations. This modelling framework, using the viscous-plastic (VP) model [123], or a derivative of it, is based upon an isotropic, plastic continuum approach whose validity relies upon statistical averages taken over a large number of floes [124]. Therefore, simply increasing the resolution of the sea ice model component will likely have little impact on the evolution of the sea ice per se (although when resolution is increased, parameterisations may be able to be better optimised). In spite of this, and of the fact that the continuum model assumptions break down at eddy-present resolutions, small-scale features can be obtained from VP continuum-based models through virtue of the high-resolution atmosphere and ocean boundary forcing. Simulations at kilometric resolutions using isotropic, plastic rheologies have been shown to generate linear kinematic features, such as leads and ridges, which look realistic, although are not well resolved and may not be oriented correctly [125].

Furthermore, being at the interface between the two, sea ice responds strongly to the forcing provided by the atmosphere and ocean components within climate models [126]. This means that changes in model resolution that lead to improvements in the mean state (i.e. bias reduction) or variability of the atmosphere or ocean models can lead to considerable improvements for the sea ice. For example, improvements to Southern Ocean circulation and SST biases can have a considerable impact on Antarctic sea ice cover [104, 111], while improved transport of warm Atlantic waters into the Arctic through Fram Strait can have a considerable impact on Arctic sea ice thickness [127].

Although continuum sea ice models are not expected to resolve small-scale dynamical features, they represent the heterogeneity of sea ice using a subgrid ice thickness distribution (ITD). Climate models with the most complexity in their sea ice components generally use a prognostic ITD to evolve the ITD explicitly at each model grid cell. This can be considered akin to a resolution increase for sea ice models and can have a considerable impact on heat exchanges over, and through, sea ice (Komuro and Suzuki, 2013). Inclusion of a prognostic ITD has been shown to have a considerable impact on sea ice evolution and feedback within climate models [128]. For example, enhancement of the (positive) ice-albedo feedback, coupled with suppression of the (negative) thickness-growth and thickness-strength (i.e. ridging) feedbacks, can lead to enhanced ice loss [129].

\section{Biogeochemistry}

Models of marine biogeochemistry are typically used within ESMs to represent the ocean's role in the global carbon cycle and increasingly used to explore how climate change may impact marine ecosystems [130, 131]. Eddy-parameterising models still permit simulation of large-scale features and trends in marine biogeochemistry [132]. However, the ocean features that drive both the climate dynamics and the dynamics of many fish species ideally require much greater model resolution and regional realism $[130,133]$. The computational cost of increased spatial resolution in models is compounded by the growing complexity of marine biogeochemistry models through expensive tracer advection [134]. Consequently, there are numerous ongoing activities to address biogeochemical complexity $[135,136]$ as well as the reduction of simulation cost $[134,137,138]$. These have important implications, for instance lengthening spin-up to reduce model drift [119] or in efficiently tuning model biogeochemistry [139]. Overall, model resolution and process complexity necessarily trade- 
off against simulation duration or experimental range. Choice of model sophistication may be clear where an end application requires only large-scale accuracy over long duration, or finescale accuracy over shorter periods. Many activities span this range, requiring an awareness in end users of the limitations that particular simulations impose in terms of spatial, physical, and biogeochemical accuracy. For example, results with idealised models suggest that the ocean carbon budget may exhibit reduced sensitivity to variations in Southern Ocean wind magnitude with explicit rather than parameterised eddies [140].

\section{Ice Sheet Modelling}

The horizontal size of Antarctic ice shelves ranges from the tiny Ferrigno ice shelf $\left(\sim 100 \mathrm{~km}^{2}\right)$ to the giant Ross ice shelf $\left(\sim 500,000 \mathrm{~km}^{2}\right)[141]$. Basal melt can also be distributed over a range of length scales [142], concentrated in the first $20 \mathrm{~km}$ near the grounding line but with kilometre-scale variation due to the presence of a network of basal channels. Vertical length scales of the ice shelf also need to be considered: with buoyant plumes of $\mathrm{O}(1) \mathrm{m}$, simulated melt is very sensitive to the vertical resolution at the ice shelf base and vertical discretisation in the ocean model as well as the computation of the thermal driving [143]. Although many ocean models include ice shelf/ ocean interactions $[144,145]$, current ESMs with eddyparameterising and eddy-present resolutions are unable to capture all the relevant processes due to the horizontal and vertical length scales. One approach is to parameterise the circulation inside the ice shelf cavity (ice pump, ice shelf melt) on scales that the models are able to resolve [144, 146].

In current ESMs, representation of fjords around Greenland glaciers is missing. Explicit representation of processes at tide water glacier fronts requires very high horizontal and vertical resolution $(\mathrm{O}(1) \mathrm{m})$ [147] due to the typical size of the buoyant plumes generated by the subglacial runoff. Therefore, parameterisation of fjord dynamics and representation of ocean/tide water glacier interactions are needed to link the glacier front to the modelled ocean. Work with detailed models of fjord dynamics [148-150] (at resolutions much finer than ESMs) and analytical models $[151,152]$ are working towards parameterisations suitable for ESMs.

The impact of cold, fresh water resulting from ice sheet melting on the large-scale ocean circulation is also resolution dependent. Convection in the subpolar North Atlantic behaves differently in volumes and timing depending on whether melt water from Greenland glaciers finds its way into the interior of the Labrador Sea or is flushed within the Labrador Current towards the south $[153,154]$. Since this boundary-interior exchange takes place via mesoscale eddies [155], it requires grid scales of $1 / 20^{\circ}$. In consequence, to correctly explore the potential response of the $\mathrm{AMOC}$ on ice sheet decay, it requires an ESM with eddy-rich resolution.

\section{Advances in Parameterising the Mesoscale for Future Earth System Models}

Current mesoscale eddy parameterisations in eddyparameterising models, based on GM, mimic baroclinic instability and act as a net sink of available potential energy. As discussed in the 'Impact of Ocean Resolution on Mean State, Variability, and Future Projections' section, GM does not fully capture the physics of eddy saturation and compensation. It has been proposed that solving an explicit eddy energy budget is critical to understanding and correctly modelling eddy saturation [156]. The new GEOMETRIC eddy parameterisation follows such an approach, using the parameterised eddy energy to rescale GM [157] and looks promising in terms of reproducing both eddy saturation and eddy compensation [158].

As discussed in the 'Resolution in Ocean Components of CMIP6 Earth System Models' section, many models in the eddy-present regime do not incorporate GM but also do not explicitly resolve the mesoscale field, which can lead to less realistic behaviour in eddy-present models than eddyparameterising ones. Scale-aware implementations of GM will allow the scheme to be used at eddy-present and eddyrich resolutions without killing the eddy field [41]. Variability in eddy-present and eddy-rich models has also been shown to differ from that in eddy-parameterised models. This is to be expected as most parameterisations are designed to only capture the mean effects of eddies and not the variability of eddies, although some recent schemes attempt to also parameterise the variability [159-162]. The choice of resolving or parameterising the mesoscale at eddy-present ('grey zone') resolutions is likely to remain difficult.

There is currently no parameterisation implemented in climate models that mimics the important transfer of kinetic energy from small to large scales, namely kinetic energy backscatter, which affects the large-scale flow [163]. Recently, several studies using idealised numerical setups have developed energy backscatter parameterisations for ocean models. There are two main categories of parameterisations currently being developed:

- A new set of momentum closures that have shown promise in mimicking kinetic energy backscatter. For example, stochastic eddy parametrisations have been developed for both eddy-parameterising and eddy-present simulations [160, 164]. The statistics of the stochastic models are crucial to mimicking eddy-mean flow interactions and improve the large-scale biases in ocean currents. Another example is a class of flow- and scale-aware parameterisations based on a non-Newtonian stress relation $[161,165,166]$. Finally, antiviscous parameterisations have also shown improvements at eddy-permitting resolution $[167,168]$, when energetically constrained.

- At eddy-parameterising resolution, part of the available potential energy extracted by the GM parameterisation 
can be re-introduced at a large scale. For example, studies have reinjected the energy lost by GM into the momentum equation using a simple anti-viscous term [169-171]. We note that this approach (a) could be combined with the new momentum closures which are more physically appropriate than an anti-viscous term [163] and (b) may have implications for computational cost due to a reduction in timestep required to satisfy the CFL criteria [171].

Beyond the mesoscale, considering parameterisation of the submesoscale for coarser resolution models will be key to future model improvement. In particular, parameterisation of other submesoscale impacts that are distinct from mixed layer eddy restratification, such as damping through submesoscale air-sea fluxes [172], lateral dispersion of pollutants and tracers [173], and submesoscale vertical transport below the mixed layer and nutrient pumping [174], is being developed. Different classes of submesoscale parameterisations, those specifically designed for use as subgrid schemes to carry forward cascades of energy, enstrophy, and tracer variance in mesoscale-resolving models, are in development [41, $161,175,176]$ and being prototyped in realistic simulations where they are shown to have benefits in less damping leading to better realism of energy and other dissipation $[41,177]$.

To satisfy the varying effective resolution versus a spatiotemporally variable mesoscale and submesoscale eddy scale, scale and flow awareness [30, 43] is essential ingredients of this class of parameterisations. One of the big advantages of scale-aware parameterisations is that they support the use of a hierarchy of resolutions as it avoids the need to retune parameterisations for each resolution $[39,41,161]$.

\section{Summary}

The choice of ocean resolution in full Earth System models will always be limited by computational resources. Although there has been notable progress in increasing ocean resolution since CMIP3, the average resolution of the ocean component is still above $50 \mathrm{~km}$ with an effective resolution on the order of $300 \mathrm{~km}$ [178] which is more than five times greater than the resolution required to resolve the Rossby radius at mid-latitudes. Pioneering ocean simulations at eddy-rich resolution offers the potential to better evaluate errors and parameterisations in lower-resolution full Earth System models with the aim of better constraining their simulation of climate.

This review has demonstrated that both the mean state of the climate and the variability are sensitive to the choice of horizontal ocean resolution. The mean state is not uniformly improved by increased resolution, and the sensitivity is generally different across key metrics such as the Atlantic meridional overturning circulation and the Antarctic circumpolar current. This demonstrates that the numerical and parameterisation choices within configurations of ocean models remain important when producing the best possible representation of the ocean. In addition to horizontal resolution, vertical coordinates and resolution are also a key factor in ocean model performance, both in terms of capturing the baroclinic modes [179] and in particular regions determined by bathymetry such as overflows and ice cavities as well as in the surface boundary layer.

Particularly relevant to the use of ocean models as a component of Earth System models is that the choice of ocean resolution has effects beyond the ocean physics itself. Difficult choices with respect to resolution will need to be made in the future to satisfy the requirements for simulating the ocean biogeochemistry and capturing the details of ocean-ice sheet interactions as well as maintaining a computational cost that allows long multi-centennial simulations both for spin-up and projections. This is likely to require implementing variable horizontal resolution so that resolution can be placed in areas of high ocean eddy activity and critical frontal or topographic features.

\section{Model Data}

Model simulation output used in Fig. 1 can be obtained via the Earth System Grid Federation (ESGF) nodes for CMIP6 HighResMIP: HadGEM3-GC3.1 [180-182], ECMWF-IFS [182, 184], CNRM-CM6-1 [185, 186], CMCCCM2-(V)HR4 [187, 188], EC-Earth3P [189, 190], MPIESM1-2 [191, 192], CESM1-3 [193, 194] and DOE-E3SM [195]. For the CMIP6 OMIP2, an archive of the model outputs and the scripts used to process the data is available at https:// doi.org/10.5281/zenodo.3685918.

Acknowledgements The authors thank the editor, Dr. Isla Simpson, for inviting this review and the two anonymous reviewers for their insightful comments. EB further acknowledges support from the European Union's Horizon 2020 research and innovation programme under grant agreement No 824084 (IS-ENES3).

Funding HTH, EB, PM, PH, MJR, and MB acknowledge the Met Office Hadley Centre Climate Programme. MJR, DP, and TA acknowledge PRIMAVERA funding received from the European Commission under Grant Agreement 641727 of the Horizon 2020 research programme. EP, TK, and AY were supported by the National Environmental Research Council (NERC) National Capability Science Multi-Centre funding for the UK Earth System Modelling project through grant NE/N018036/1 and the EU Horizon 2020 CRESCENDO project, grant number 641816. BFK is supported by ONR N00014-17-1-2963, NSF 1350795 and 1655221, and NOAA NA19OAR4310366. RB was supported by NSF's Southern Ocean Carbon and Climate Observations and Modeling (SOCCOM) Project under NSF Award PLR-1425989. DPM is supported by NERC NE/R000999/1. TA acknowledges PRACE for awarding us access to MN4 supercomputer, hosted by BSC, Spain. The CESM1.3 simulations are completed through the International Laboratory for High Resolution Earth System Prediction (iHESP) - a collaboration among QNLM, TAMU, and NCAR, from which QZ, BG, and FC acknowledge funding. LZ was supported by NSF-GEO 1912357 and NOAA CVP NA19OAR4310364. 


\section{Compliance with Ethical Standards}

Conflict of Interest On behalf of all authors, the corresponding author states that there is no conflict of interest.

Open Access This article is licensed under a Creative Commons Attribution 4.0 International License, which permits use, sharing, adaptation, distribution and reproduction in any medium or format, as long as you give appropriate credit to the original author(s) and the source, provide a link to the Creative Commons licence, and indicate if changes were made. The images or other third party material in this article are included in the article's Creative Commons licence, unless indicated otherwise in a credit line to the material. If material is not included in the article's Creative Commons licence and your intended use is not permitted by statutory regulation or exceeds the permitted use, you will need to obtain permission directly from the copyright holder. To view a copy of this licence, visit http://creativecommons.org/licenses/by/4.0/.

\section{References}

1. Palmer MD, McNeall DJ. Internal variability of Earth's energy budget simulated by CMIP5 climate models. Environ Res Lett. 2014;9:34016. https://doi.org/10.1088/1748-9326/9/3/034016.

2. Church JA, Clark PU, Cazenave A, et al (2013) Sea level change. In: Stocker TF, Qin D, Plattner G-K, et al (eds) Climate change 2013: the physical science basis. Contribution of Working Group I to the Fifth Assessment Report of the IPCC. Cambridge University Press, pp 1137-1216.

3. Minobe S, Kuwano-Yoshida A, Komori N, et al. Influence of the Gulf Stream on the troposphere. Nature. 2008;452:206-9. https:// doi.org/10.1038/nature06690.

4. DeVries T, Holzer M, Primeau F. Recent increase in oceanic carbon uptake driven by weaker upper-ocean overturning. Nature. 2017;542:215. https://doi.org/10.1038/nature21068.

5. Kessler A, Tjiputra J. The Southern Ocean as a constraint to reduce uncertainty in future ocean carbon sinks. Earth Syst Dyn. 2016;7:295-312. https://doi.org/10.5194/esd-7-295-2016.

6. Levermann A, Winkelmann R, Albrecht T, et al. Projecting Antarctica's contribution to future sea level rise from basal ice shelf melt using linear response functions of 16 ice sheet models (LARMIP-2). Earth Syst Dyn. 2020;11:35-76. https://doi.org/10. 5194/esd-11-35-2020.

7. Shepherd A, Ivins E, Rignot E, et al. Mass balance of the Greenland ice sheet from 1992 to 2018. Nature. 2020;579:2339. https://doi.org/10.1038/s41586-019-1855-2.

8. Griffies SM, Böning C, Bryan FO, et al. Developments in ocean climate modelling. Ocean Model. 2000;2:123-92.

9. Eyring V, Bony S, Meehl GA, et al. Overview of the coupled model intercomparison project phase 6 (CMIP6) experimental design and organization. Geosci Model Dev. 2016;9:1937-58. https://doi.org/10.5194/gmd-9-1937-2016.

10. Madec G, Bourdallé-Badie R, Chanut J, et al. NEMO ocean engine. 2019. https://doi.org/10.5281/ZENODO.3878122.

11. Smith R, Jones P, Briegleb BP, et al (2010) The parallel ocean program (POP) reference manual: ocean component of the community climate system model (CCSM).

12. Sidorenko D, Rackow T, Jung T, et al. Towards multi-resolution global climate modeling with ECHAM6-FESOM. Part I: model formulation and mean climate. Clim Dyn. 2015;44:757-80. https://doi.org/10.1007/s00382-014-2290-6.

13. Petersen MR, Asay-Davis XS, Berres AS, Chen Q, Feige N, Hoffman MJ, et al. An evaluation of the ocean and sea ice climate of E3SM using MPAS and interannual CORE-II forcing. J Adv Model Earth Syst. 2019;11:1438-58. https://doi.org/10.1029/ 2018MS001373.

14. Volodin EM, Mortikov EV, Kostrykin SV, Galin VY, Lykossov VN, Gritsun AS, et al. Simulation of the present-day climate with the climate model INMCM5. Clim Dyn. 2017;49:3715-34. https://doi.org/10.1007/s00382-017-3539-7.

15. Adcroft A, Anderson W, Balaji V, Blanton C, Bushuk M, Dufour $\mathrm{CO}$, et al. The GFDL global ocean and sea ice model OM4.0: model description and simulation features. J Adv Model Earth Syst. 2019;11: 3167-211. https://doi.org/10.1029/2019MS001726.

16. Guo C, Bentsen M, Bethke I, et al. Description and evaluation of NorESM1-F: a fast version of the Norwegian Earth System Model (NorESM). Geosci Model Dev. 2019;12:343-62. https://doi.org/ 10.5194/gmd-12-343-2019.

17. Haarsma RJ, Roberts MJ, Vidale PL, Senior CA, Bellucci A, Bao $\mathrm{Q}$, et al. High resolution model intercomparison project (HighResMIP v1.0) for CMIP6. Geosci Model Dev. 2016;9: 4185-208. https://doi.org/10.5194/gmd-9-4185-2016.

18. Hewitt HT, Bell MJ, Chassignet EP, et al. Will high-resolution global ocean models benefit coupled predictions on short-range to climate timescales? Ocean Model. 2017;120:120-36. https://doi. org/10.1016/j.ocemod.2017.11.002.

19. Roberts MJ, Vidale PL, Senior C, et al. The benefits of global high resolution for climate simulation: process understanding and the enabling of stakeholder decisions at the regional scale. Bull Am Meteorol Soc. 2018;99:2341-59. https://doi.org/10.1175/BAMSD-15-00320.1.

20. Hirschi JJ-M, Barnier B, Böning C, et al. The Atlantic meridional overturning circulation in high resolution models. J Geophys Res Ocean. 2020;125:e2019JC015522. https://doi.org/10.1029/ 2019JC015522.

21. Roberts CD, Vitart F, Balmaseda MA, Molteni F. The time-scaledependent response of the wintertime North Atlantic to increased ocean model resolution in a coupled forecast model. J Clim. 2020;33:3663-89. https://doi.org/10.1175/JCLI-D-19-0235.1.

22. Fox-Kemper B (2018) Notions for the motions of the oceans. In: Chassignet EP, Pascual A, Tintore J, Verron J (eds) New Frontiers in Operational Oceanography.

23. Griffies SM, Danabasoglu G, Durack PJ, et al. OMIP contribution to CMIP6: experimental and diagnostic protocol for the physical component of the ocean model intercomparison project. Geosci Model Dev. 2016. https://doi.org/10.5194/gmd-9-3231-2016.

24. Tsujino H, Urakawa LS, Griffies SM, Danabasoglu G, Adcroft AJ, Amaral AE, et al. Evaluation of global ocean and d sea-ice model simulations based on the experimental protocols of the ocean model intercomparison project phase 2 (OMIP-2). Geosci Model Dev. 2020;13:3643-708. https://doi.org/10.5194/gmd-2019-363.

25. Chassignet EP, Yeager SG, Fox-Kemper B, et al. Impact of horizontal resolution on global ocean-sea-ice model simulations based on the experimental protocols of the ocean model intercomparison project phase 2 (OMIP-2). Geosci Model Dev. 2020. https://doi.org/10.5194/gmd-2019-374.

26. Golaz J-C, Caldwell PM, Van Roekel LP, et al. The DOE E3SM coupled model version 1: overview and evaluation at standard resolution. J Adv Model Earth Syst. 2019;11:2089-129. https:// doi.org/10.1029/2018MS001603.

27. Mauritsen T, Bader J, Becker T, et al. Developments in the MPI-M Earth System model version 1.2 (MPI-ESM1.2) and its response to increasing $\mathrm{CO}_{2}$. J Adv Model Earth Syst. 2019;11:998-1038. https://doi.org/10.1029/2018MS001400.

28. Séférian R, Nabat P, Michou M, et al. Evaluation of CNRM Earth System model, CNRM-ESM2-1: role of Earth System processes in present-day and future climate. J Adv Model Earth Syst. 2019;11:4182-227. https://doi.org/10.1029/2019MS001791. 
29. Sellar AA, Jones CG, Mulcahy JP, et al. UKESM1: description and evaluation of the U.K. Earth System model. J Adv Model Earth Syst. 2019;11:4513-58. https://doi.org/10.1029/2019MS001739.

30. Hallberg R. Using a resolution function to regulate parameterizations of oceanic mesoscale eddy effects. Ocean Model. 2013;72: 92-103. https://doi.org/10.1016/J.OCEMOD.2013.08.007.

31. Tulloch R, Marshall J, Hill C, Smith KS. Scales, growth rates, and spectral fluxes of baroclinic instability in the ocean. J Phys Oceanogr. 2011;41:1057-76. https://doi.org/10.1175/2011JPO4404.1.

32. Griffies SM, Winton M, Anderson WG, et al. Impacts on ocean heat from transient mesoscale eddies in a hierarchy of climate models. J Clim. 2015;28:952-77. https://doi.org/10.1175/JCLID-14-00353.1.

33. Gent PR, McWilliams JC. Isopycnal mixing in ocean circulation models. J Phys Oceanogr. 1990;20:150-5.

34. Biastoch A, Sein D, Durgadoo JV, et al. Simulating the Agulhas system in global ocean models-nesting vs. multi-resolution unstructured meshes. Ocean Model. 2018;121:117-31. https://doi. org/10.1016/j.ocemod.2017.12.002.

35. Sidorenko D, Goessling HF, Koldunov NV, et al. Evaluation of FESOM2.0 coupled to ECHAM6.3: preindustrial and HighResMIP simulations. J Adv Model Earth Syst. 2019;11: 3794-815. https://doi.org/10.1029/2019MS001696.

36. Storkey D, Blaker AT, Mathiot P, et al. UK global ocean GO6 and GO7: a traceable hierarchy of model resolutions. Geosci Model Dev. 2018;11:3187-213. https://doi.org/10.5194/gmd-11-3187-2018.

37. Kiss AE, Hogg AM, Hannah N, et al. ACCESS-OM2 v1.0: a global ocean \& sea ice model at three resolutions. Geosci Model Dev. 2020;13:401-42. https://doi.org/10.5194/gmd-13-401-2020.

38. Fox-Kemper B, Danabasoglu G, Ferrari R, Griffies SM, Hallberg RW, Holland MM, et al. Parameterization of mixed layer eddies III: implementation and impact in global ocean climate simulations. Ocean Model. 2011;39:61-78. https://doi.org/10.1016/j. ocemod.2010.09.002.

39. Fox-Kemper B, Menemenlis D (2008) Can large eddy simulation techniques improve mesoscale rich ocean models? Ocean Model. an Eddying Regime 319-337.

40. Brüggemann N, Eden C. Evaluating different parameterizations for mixed layer eddy fluxes induced by baroclinic instability. J Phys Oceanogr. 2014;44:2524-46. https://doi.org/10.1175/JPOD-13-0235.1.

41. Pearson B, Fox-Kemper B, Bachman S, Bryan F. Evaluation of scale-aware subgrid mesoscale eddy models in a global eddy-rich model. Ocean Model. 2017;115:42-58. https://doi.org/10.1016/j. ocemod.2017.05.007.

42. Bentsen M, Bethke I, Debernard JB, et al. The Norwegian Earth System model, NorESM1-M-part 1: description and basic evaluation of the physical climate. Geosci Model Dev. 2013;6:687720. https://doi.org/10.5194/gmd-6-687-2013.

43. Dong J, Fox-Kemper B, Zhang H, Dong C. The size of submesoscale baroclinic instability globally. J Phys Oceanogr. 2020. https://doi.org/10.1175/JPO-D-20-0043.1.

44. Schubert R, Schwarzkopf FU, Baschek B, Biastoch A. Submesoscale impacts on mesoscale Agulhas dynamics. J Adv Model Earth Syst. 2019;11:2745-67. https://doi.org/10.1029/ 2019MS001724

45. Sasaki H, Sasai Y, Kawahara S, et al (2004) A series of eddyresolving ocean simulations in the world ocean-OFES (OGCM for the earth simulator) project. In: Oceans '04 MTS/IEEE TechnoOcean '04 (IEEE Cat. No.04CH37600). IEEE, pp 1535-1541.

46. Chassignet EP, Marshall DP (2008) Gulf Stream separation in numerical ocean models. In: Hecht MW, Hasumi H (eds) Ocean modeling in an eddying regime. American Geophysical Union (AGU), pp. 39-61.

47. Delworth TL, Rosati A, Anderson W, Adcroft AJ, Balaji V, Benson R, et al. Simulated climate and climate change in the
GFDL CM2.5 high-resolution coupled climate model. J Clim. 2012;25:2755-81. https://doi.org/10.1175/JCLI-D-11-00316.1.

48. Yu Y, Liu H, Lin P. A quasi-global $1 / 10^{\circ}$ eddy-resolving ocean general circulation model and its preliminary results. Chin Sci Bull. 2012;57:3908-16. https://doi.org/10.1007/s11434-0125234-8.

49. Small RJ, Bacmeister J, Bailey D, et al. A new synoptic scale resolving global climate simulation using the Community Earth System Model. J Adv Model Earth Syst. 2014;6:1065-94. https:// doi.org/10.1002/2014MS000363.

50. Chassignet EP, $\mathrm{Xu} X$. Impact of horizontal resolution $\left(1 / 12^{\circ}\right.$ to $1 / 50^{\circ}$ ) on Gulf Stream separation, penetration, and variability. J Phys Oceanogr. 2017;47:1999-2021. https://doi.org/10.1175/ JPO-D-17-0031.1.

51. Chassignet EP, Yeager SG, Fox-Kemper B, et al. Impact of horizontal resolution on the energetics of global ocean-sea-ice model simulations. CLIVAR Var. 2020;18:23-30. https://doi.org/10. 5065/g8w0-fy32.

52. Moreton S, Ferreira D, Roberts M, Hewitt H. Evaluating surface eddy properties in coupled climate simulations with "eddy-present" and "eddy-rich" ocean resolution. Ocean Model. 2020;147: 101567. https://doi.org/10.1016/j.ocemod.2020.101567.

53. Fox-Kemper B, Pedlosky J. Wind-driven barotropic gyre I: circulation control by eddy vorticity fluxes to an enhanced removal region. J Mar Res. 2004;62:169-93. https://doi.org/10.1357/ 002224004774201681.

54. Berloff P, Hogg AMC, Dewar W, et al. The turbulent oscillator: a mechanism of low-frequency variability of the wind-driven ocean gyres. J Phys Oceanogr. 2007;37:2363-86. https://doi.org/10. 1175/JPO3118.1.

55. Biastoch A, Durgadoo JV, Morrison AK, et al. Atlantic multidecadal oscillation covaries with Agulhas leakage. Nat Commun. 2015;6:10082. https://doi.org/10.1038/ncomms10082.

56. Lübbecke JF, Durgadoo JV, Biastoch A (2015) Contribution of increased agulhas leakage to tropical Atlantic warming. J Clim 28. https://doi.org/10.1175/JCLI-D-15-0258.1.

57. Schwarzkopf FU, Biastoch A, Böning CW, et al. The INALT familya set of high-resolution nests for the Agulhas Current system within global NEMO ocean/sea-ice configurations. Geosci Model Dev. 2019;12:3329-55. https://doi.org/10.5194/gmd-12-3329-2019.

58. Rühs S, Schwarzkopf FU, Speich S, Biastoch A. Cold vs. warm water route-sources for the upper limb of the Atlantic meridional overturning circulation revisited in a high-resolution ocean model. Ocean Sci. 2019;15:489-512. https://doi.org/10.5194/os-15-489-2019.

59. Ma X, Jing Z, Chang P, et al. Western boundary currents regulated by interaction between ocean eddies and the atmosphere. Nature. 2016;535:533-7. https://doi.org/10.1038/nature18640.

60. Renault L, Molemaker MJ, McWilliams JC, et al. Modulation of wind work by oceanic current interaction with the atmosphere. $\mathrm{J}$ Phys Oceanogr. 2016;46:1685-704. https://doi.org/10.1175/JPOD-15-0232.1.

61. Zhang Z, Tian J, Qiu B, et al. Observed 3D structure, generation, and dissipation of oceanic mesoscale eddies in the South China Sea. Sci Rep. 2016;6:24349. https://doi.org/10.1038/srep24349.

62. Oerder V, Colas F, Echevin V, et al. Impacts of the mesoscale oceanatmosphere coupling on the Peru-Chile ocean dynamics: the currentinduced wind stress modulation. J Geophys Res Ocean. 2018;123: 812-33. https://doi.org/10.1002/2017JC013294.

63. Ajayi AO, Le Sommer J, Chassignet EP, et al (2020) Diagnosing cross-scale kinetic energy exchanges from two submesoscale permitting ocean models. J Adv Model Earth Syst revised

64. Ajayi AO, Le Sommer J, Chassignet EP, et al. Spatial and temporal variability of the North Atlantic eddy field at scale less than 100 km. J Geophys Res. 2020;125:e2019JC015827. https://doi.org/ $10.1029 / 2019 J C 015827$. 
65. Bolton T, Zanna L. Applications of deep learning to ocean data inference and subgrid parameterization. J Adv Model Earth Syst. 2019;11:376-99. https://doi.org/10.1029/2018MS001472.

66. Zanna L, Bolton T. Data-driven equation discovery of ocean mesoscale closures. Geophys Res Lett. 2020;47:e2020GL088376. https://doi.org/10.1029/2020GL088376.

67. Johns WE, Baringer MO, Beal LM, et al. Continuous, Array-based estimates of Atlantic Ocean heat transport at $26.5^{\circ} \mathrm{N}$. J Clim. 2010;24: 2429-49. https://doi.org/10.1175/2010JCLI3997.1.

68. Smeed DA, Josey SA, Beaulieu C, et al. The North Atlantic Ocean is in a state of reduced overturning. Geophys Res Lett. 2018;45: 1527-33. https://doi.org/10.1002/2017GL076350.

69. Roberts CD, Jackson L, McNeall D. Is the 2004-2012 reduction of the Atlantic meridional overturning circulation significant? Geophys Res Lett. 2014;41:3204-10. https://doi.org/10.1002/ 2014GL059473.

70. Baehr J, Cunnningham S, Haak H, Heimbach P, Kanzow T, Marotzke J. Observed and simulated estimates of the meridional overturning circulation at $26.5 \mathrm{~N}$ in the Atlantic. Ocean Sci. 2009;5:575-89. https://doi.org/10.5194/os-5-575-2009.

71. Balan Sarojini B, Gregory JM, Tailleux R, et al. High frequency variability of the Atlantic meridional overturning circulation. Ocean Sci. 2011;7:471-86. https://doi.org/10.5194/os-7-471-2011.

72. Roberts CD, Waters J, Peterson KA, et al. Atmosphere drives recent interannual variability of the Atlantic meridional overturning circulation at $26.5^{\circ} \mathrm{N}$. Geophys Res Lett. $2013 ; 40$ : 5164-70. https://doi.org/10.1002/grl.50930.

73. Roberts M, Jackson LC, Roberts CD, et al. Sensitivity of the Atlantic meridional overturning circulation to model resolution in CMIP6 HighResMIP simulations and implications for future changes. J Adv Model Earth Syst in press. 2020;12: e2019MS002014.

74. Donohue KA, Tracey KL, Watts DR, et al. Mean Antarctic circumpolar current transport measured in Drake Passage. Geophys Res Lett. 2016;43:11,711-760,767. https://doi.org/10.1002/ 2016GL070319.

75. Jackson LC, Roberts MJ, Hewitt HT, et al (2020) Does ocean resolution affect the rate of AMOC weakening? Clim Dyn in press

76. Heuzé C. North Atlantic deep water formation and AMOC in CMIP5 models. Ocean Sci. 2017;13:609-22. https://doi.org/10. 5194/os-13-609-2017.

77. Quadfasel D, KäSe R (2007) Present-day manifestation of the Nordic Seas overflows. Ocean Circ Mech Impacts-Past Futur Chang Merid Overturning 75-89.

78. Legg S, Briegleb B, Chang Y, et al. Improving oceanic overflow representation in climate models: the gravity current entrainment climate process team. Bull Am Meteorol Soc. 2009;90:657-70. https://doi.org/10.1175/2008BAMS2667.1.

79. Treguier AM, Deshayes J, Lique C, et al (2012) Eddy contributions to the meridional transport of salt in the North Atlantic. $\mathrm{J}$ Geophys Res Ocean 117. https://doi.org/10.1029/2012JC007927.

80. Wang H, Legg SA, Hallberg RW. Representations of the Nordic Seas overflows and their large scale climate impact in coupled models. Ocean Model. 2015;86:76-92. https://doi.org/10.1016/j. ocemod.2014.12.005.

81. Danabasoglu G, Yeager SG, Bailey D, Behrens E, Bentsen M, Bi D, et al. North Atlantic simulations in coordinated ocean-ice reference experiments phase II (CORE-II). Part I: mean states. Ocean Model. 2014;73:76-107. https://doi.org/10.1016/j.ocemod.2013.10.005.

82. Yeager S, Danabasoglu G. Sensitivity of Atlantic meridional overturning circulation variability to parameterized Nordic Sea overflows in CCSM4. J Clim. 2011;25:2077-103. https://doi. org/10.1175/JCLI-D-11-00149.1.

83. Colombo P, Barnier B, Penduff T, et al (2020) Representation of the Denmark Strait overflow in a z-coordinate eddying configuration of the NEMO (v3.6) ocean model: resolution and parameter impacts. Geosci Model Dev 3347-3371. https://doi.org/10.5194/ gmd-13-3347-2020

84. Talandier C, Deshayes J, Treguier A-M, et al. Improvements of simulated western North Atlantic current system and impacts on the AMOC. Ocean Model. 2014;76:1-19. https://doi.org/10.1016/ j.ocemod.2013.12.007.

85. Beadling RL, Russell JL, Stouffer RJ, et al. Representation of Southern Ocean properties across coupled model intercomparison project generations: CMIP3 to CMIP6. J Clim. 2020;33:6555-81 https://doi.org/10.1175/JCLI-D-19-0970.1.

86. Marshall J, Speer K. Closure of the meridional overturning circulation through Southern Ocean upwelling. Nat Geosci. 2012;5: 171-80. https://doi.org/10.1038/ngeo1391.

87. Farneti R, Downes SM, Griffies SM, Marsland SJ, Behrens E, Bentsen $\mathrm{M}$, et al. An assessment of Antarctic circumpolar current and Southern Ocean meridional overturning circulation during 1958-2007 in a suite of interannual CORE-II simulations. Ocean Model. 2015;94:84-120. https://doi.org/10.1016/j.ocemod.2015.07.009.

88. Bishop SP, Gent PR, Bryan FO, et al. Southern Ocean overturning compensation in an eddy-resolving climate simulation. J Phys Oceanogr. 2016;46:1575-92.

89. Meijers AJSS, Shuckburgh E, Bruneau N, et al. Representation of the Antarctic circumpolar current in the CMIP5 climate models and future changes under warming scenarios. J Geophys Res. 2012;117:C12008. https://doi.org/10.1029/2012JC008412.

90. Yamazaki K, Sexton DMH, Rostron J, et al (2020) A perturbed parameter ensemble of HadGEM3-GC3.05 coupled model projections: part 2: global performance and future changes. Clim Dyn submitted

91. Held IM, Guo H, Adcroft A, et al. Structure and performance of GFDL's CM4.0 climate model. J Adv Model Earth Syst. 2019;11: 3691-727. https://doi.org/10.1029/2019MS001829.

92. Dunne JP, Horowitz LW, Adcroft AJ, et al. The GFDL Earth System model version 4.1 (GFDL-ESM4.1): model description and simulation characteristics. J Adv Model Earth Syst. 2020;12: e2019MS002015. https://doi.org/10.1029/2019MS002015.

93. Hewitt HT, Roberts MJ, Hyder P, et al. The impact of resolving the Rossby radius at mid-latitudes in the ocean: results from a high-resolution version of the Met Office GC2 coupled model. Geosci Model Dev. 2016;9:3655. https://doi.org/10.5194/gmd-93655-2016.

94. Gordon AL. Deep Antarctic convection west of Maud Rise. J Phys Oceanogr. 1978;8:600-12. https://doi.org/10.1175/15200485(1978)008<0600:DACWOM>2.0.CO;2.

95. Carsey FD. Microwave observation of the Weddell Polynya. Mon Weather Rev. 1980;108:2032-44. https://doi.org/10.1175/15200493(1980)108<2032:MOOTWP>2.0.CO;2.

96. Campbell EC, Wilson EA, Moore GWK, et al. Antarctic offshore polynyas linked to Southern Hemisphere climate anomalies. Nature. 2019. https://doi.org/10.1038/s41586-019-1294-0.

97. Munday DR, Johnson HL, Marshall DP. Eddy saturation of equilibrated circumpolar currents. J Phys Oceanogr. 2013;43:507-32. https://doi.org/10.1175/JPO-D-12-095.1.

98. Gent PR. Effects of Southern Hemisphere wind changes on the meridional overturning circulation in ocean models. Annu Rev Mar Sci. 2016;8:79-94. https://doi.org/10.1146/annurev-marine122414-033929.

99. Gnanadesikan A. A simple predictive model for the structure of the oceanic pycnocline. Science. 1999;283:2077-9. https://doi. org/10.1126/science.283.5410.2077.

100. Voldoire A, Saint-Martin D, Sénési S, et al. Evaluation of CMIP6 DECK experiments with CNRM-CM6-1. J Adv Model Earth Syst. 2019;11:2177-213. https://doi.org/10.1029/ 2019MS001683.

101. Hyder P, Edwards JM, Allan RP, Hewitt HT, Bracegirdle TJ, Gregory JM, et al. Critical Southern Ocean climate model biases 
traced to atmospheric model cloud errors. Nat Commun. 2018;9: 3625. https://doi.org/10.1038/s41467-018-05634-2.

102. Menary MB, Kuhlbrodt T, Ridley J, et al. Preindustrial control simulations with HadGEM3-GC3.1 for CMIP6. J Adv Model Earth Syst. 2018;10:3049-75. https://doi.org/10.1029/ 2018MS001495.

103. Matthes K, Biastoch A, Wahl S, et al. The flexible ocean and climate infrastructure version 1 (FOCI1): mean state and variability. Geosci Model Dev. 2020;13:2533-68. https://doi.org/10. 5194/gmd-13-2533-2020.

104. Roberts MJ, Baker A, Blockley EW, et al. Description of the resolution hierarchy of the global coupled HadGEM3-GC3.1 model as used in CMIP6 HighResMIP experiments. Geosci Model Dev. 2019. https://doi.org/10.5194/gmd-12-4999-2019.

105. Bock L, Lauer A, Eyring V, et al (2020) Quantifying progress across different CMIP phases with the ESMValTool. J Geophys Res submitted

106. Mahadevan A, D'Asaro E, Lee C, Perry MJ. Eddy-driven stratification initiates North Atlantic spring phytoplankton blooms. Science. 2012;337:54 LP-58. https://doi.org/10.1126/science.1218740.

107. Omand MM, D'Asaro EA, Lee CM, et al. Eddy-driven subduction exports particulate organic carbon from the spring bloom. Science. 2015;348:222 LP-225. https://doi.org/10.1126/science.1260062.

108. Johnson L, Lee CM, D'Asaro EA. Global estimates of lateral springtime restratification. J Phys Oceanogr. 2016;46:1555-73. https://doi.org/10.1175/JPO-D-15-0163.1.

109. Huang CJ, Qiao F, Dai D. Evaluating CMIP5 simulations of mixed layer depth during summer. J Geophys Res Ocean. 2014;119:2568-82. https://doi.org/10.1002/2013JC009535.

110. Damerell GM, Heywood KJ, Calvert D, et al. A comparison of five surface mixed layer models with a year of observations in the North Atlantic. Prog Oceanogr. 2020. https://doi.org/10.1016/j. pocean.2020.102316

111. Rackow T, Sein DV, Semmler T, et al. Sensitivity of deep ocean biases to horizontal resolution in prototype CMIP6 simulations with AWI-CM1.0. Geosci Model Dev. 2019;12:2635-56. https://doi.org/10.5194/gmd-12-2635-2019.

112. Megann A. Estimating the numerical diapycnal mixing in an eddy-permitting ocean model. Ocean Model. 2018;121:19-33. https://doi.org/10.1016/j.ocemod.2017.11.001.

113. Zhang Y, Vallis GK. Ocean heat uptake in eddying and non-eddying ocean circulation models in a warming climate. J Phys Oceanogr. 2013;43:2211-29. https://doi.org/10.1175/JPO-D-12-078.1.

114. Marshall DP, Zanna L. A conceptual model of ocean heat uptake under climate change. J Clim. 2014;27:8444-65. https://doi.org/ 10.1175/JCLI-D-13-00344.1.

115. Morrison AK, Griffies SM, Winton M, et al. Mechanisms of Southern Ocean heat uptake and transport in a global eddying climate model. J Clim. 2016;29:2059-75. https://doi.org/10. 1175/JCLI-D-15-0579.1.

116. Stewart KD, Hogg AM. Southern Ocean heat and momentum uptake are sensitive to the vertical resolution at the ocean surface. Ocean Model. 2019;143:101456. https://doi.org/10.1016/j. ocemod.2019.101456.

117. Kuhlbrodt T, Gregory JM. Ocean heat uptake and its consequences for the magnitude of sea level rise and climate change. Geophys Res Lett. 2012;39:L18608. https://doi.org/10.1029/ 2012GL052952.

118. Sen GA, Jourdain NC, Brown JN, Monselesan D. Climate drift in the CMIP5 models. J Clim. 2013;26:8597-615. https://doi.org/10. 1175/JCLI-D-12-00521.1.

119. Séférian R, Gehlen M, Bopp L, et al. Inconsistent strategies to spin up models in CMIP5: implications for ocean biogeochemical model performance assessment. Geosci Model Dev. 2016;9: 1827-51. https://doi.org/10.5194/gmd-9-1827-2016.
120. Bronselaer B, Zanna L. Heat and carbon coupling reveals ocean warming due to circulation changes. Nature. 2020;584:227-33. https://doi.org/10.1038/s41586-020-2573-5.

121. Hunke E, Allard R, Blain P, et al (2020) Should sea-ice modeling tools designed for climate research be used for short-term forecasting? Curr Clim Chang Reports in press

122. Blockley E, Vancoppenolle M, Hunke E, et al. The future of sea ice modeling: where do we go from here? Bull Am Meteorol Soc. 2020;101:E1304-11. https://doi.org/10.1175/BAMS-D-20-0073.1.

123. Hibler WD. A dynamic thermodynamic sea ice model. J Phys Oceanogr. 1979;9:815-46.

124. Feltham DL. Sea ice rheology. Annu Rev Fluid Mech. 2008;40:91112. https://doi.org/10.1146/annurev.fluid.40.111406.102151.

125. Hutter N, Losch M. Feature-based comparison of sea ice deformation in lead-permitting sea ice simulations. Cryosph. 2020;14:93113. https://doi.org/10.5194/tc-14-93-2020.

126. Docquier D, Grist JP, Roberts MJ, Roberts CD, Semmler T, Ponsoni L, et al. Impact of model resolution on Arctic Sea ice and North Atlantic Ocean heat transport. Clim Dyn. 2019;53: 4989-5017. https://doi.org/10.1007/s00382-019-04840-y.

127. Kuhlbrodt T, Jones CG, Sellar A, et al. The low-resolution version of HadGEM3 GC3.1: development and evaluation for global climate. J Adv Model Earth Syst. 2018;10:2865-88. https://doi.org/ 10.1029/2018MS001370.

128. Massonnet F, Barthélemy A, Worou K, et al. On the discretization of the ice thickness distribution in the NEMO3.6-LIM3 global ocean-sea ice model. Geosci Model Dev. 2019;12:3745-58. https://doi.org/10.5194/gmd-12-3745-2019.

129. Holland MM, Bitz CM, Hunke EC, et al. Influence of the sea ice thickness distribution on polar climate in CCSM3. J Clim. 2006;19:2398-414. https://doi.org/10.1175/JCLI3751.1.

130. Popova E, Yool A, Byfield V, et al. From global to regional and back again: common climate stressors of marine ecosystems relevant for adaptation across five ocean warming hotspots. Glob Chang Biol. 2016;22:2038-53. https://doi.org/10.1111/gcb.13247.

131. Tittensor DP, Eddy TD, Lotze HK, et al. A protocol for the intercomparison of marine fishery and ecosystem models: Fish-MIP v1.0. Geosci Model Dev. 2018;11:1421-42. https://doi.org/10. 5194/gmd-11-1421-2018.

132. Yool A, Popova EE, Coward AC. Future change in ocean productivity: is the Arctic the new Atlantic? J Geophys Res Ocean. 2015;120:7771-90. https://doi.org/10.1002/2015JC011167.

133. Moullec F, Barrier N, Drira S, et al. An end-to-end model reveals losers and winners in a warming Mediterranean Sea. Front Mar Sci. 2019;6:345. https://doi.org/10.3389/fmars.2019.00345.

134. Kwiatkowski L, Yool A, Allen J-I, et al. iMarNet: an ocean biogeochemistry model intercomparison project within a common physical ocean modelling framework. Biogeosciences. 2014;11: 7291-304. https://doi.org/10.5194/bg-11-7291-2014.

135. Galbraith ED, Dunne JP, Gnanadesikan A, et al. Complex functionality with minimal computation: promise and pitfalls of reduced-tracer ocean biogeochemistry models. J Adv Model Earth Syst. 2015;7:2012-28. https://doi.org/10.1002/ 2015 MS000463.

136. Kriest I. Calibration of a simple and a complex model of global marine biogeochemistry. Biogeosciences. 2017;14:4965-84. https://doi.org/10.5194/bg-14-4965-2017.

137. Berthet S, Séférian R, Bricaud C, Chevallier M, Voldoire A, Ethé C. Evaluation of an online grid-coarsening algorithm in a global eddy-admitting ocean biogeochemical model. J Adv Model Earth Syst. 2019;11:1759-83. https://doi.org/10.1029/2019MS001644.

138. Bricaud C, Le Sommer J, Gurvan M, et al (2020) Multi-grid algorithm for passive tracer transport in NEMO ocean circulation model: a case study with NEMO OGCM (version 3.6). Geosci Model Dev Discuss in Review 1-32. https://doi.org/10.5194/gmd-2019-341 
139. Kriest I, Kähler P, Koeve W, et al. One size fits all?-calibrating an ocean biogeochemistry model for different circulations. Biogeosciences. 2020;17:3057-82. https://doi.org/10.5194/bg17-3057-2020.

140. Munday DR, Johnson HL, Marshall DP. Impacts and effects of mesoscale ocean eddies on ocean carbon storage and atmospheric $\mathrm{pCO}_{2}$. Glob Biogeochem Cycles. 2014;28:877-96. https://doi. org/10.1002/2014GB004836.

141. Rignot E, Jacobs S, Mouginot J, Scheuchl B. Ice-shelf melting around Antarctica. Science. 2013;341:266-70. https://doi.org/10. 1126/science.1235798.

142. Dutrieux P, Vaughan DG, Corr HFJ, Jenkins A, Holland PR, Joughin I, et al. Pine Island glacier ice shelf melt distributed at kilometre scales. Cryosphere. 2013;7:16649. https://doi.org/10. 5194/tc-7-1543-2013.

143. Gwyther DE, Kusahara K, Asay-Davis XS, et al. Vertical processes and resolution impact ice shelf basal melting: a multi-model study. Ocean Model. 2020;147:101569. https://doi.org/10.1016/j. ocemod.2020.101569.

144. Mathiot P, Jenkins A, Harris C, Madec G (2017) Explicit representation and parametrised impacts of under ice shelf seas in the Z*-coordinate ocean model NEMO 3.6. Geosci Model Dev 10. https://doi.org/10.5194/gmd-10-2849-2017

145. Zhou Q, Hattermann T. Modeling ice shelf cavities in the unstructured-grid, finite volume community ocean model: implementation and effects of resolving small-scale topography. Ocean Model. 2020;146:101536. https://doi.org/10.1016/j.ocemod.2019.101536.

146. Favier L, Jourdain NC, Jenkins A, et al (2019) Assessment of subshelf melting parameterisations using the ocean-ice-sheet coupled model NEMO(v3.6)-Elmer/Ice(v8.3). Geosci Model Dev 12. https://doi.org/10.5194/gmd-12-2255-2019

147. Xu Y, Rignot E, Fenty I, et al. Subaqueous melting of Store Glacier, west Greenland from three-dimensional, high-resolution numerical modeling and ocean observations. Geophys Res Lett. 2013;40:4648-53. https://doi.org/10.1002/grl.50825.

148. Cowton T, Slater D, Sole A, et al. Modeling the impact of glacial runoff on fjord circulation and submarine melt rate using a new subgrid-scale parameterization for glacial plumes. J Geophys Res Ocean. 2015;120:796-812. https://doi.org/10.1002/2014JC010324.

149. Gladish C V., Holland DM, Rosing-Asvid A, et al (2015) Oceanic boundary conditions for Jakobshavn Glacier. Part I: variability and renewal of Ilulissat Icefjord waters, 2001-14. J Phys Oceanogr 45. https://doi.org/10.1175/JPO-D-14-0044.1.

150. Carroll D, Sutherland DA, Shroyer EL, et al (2017) Subglacial discharge-driven renewal of tidewater glacier fjords. J Geophys Res Ocean 122. https://doi.org/10.1002/2017JC012962.

151. Jenkins A (2011) Convection-driven melting near the grounding lines of ice shelves and tidewater glaciers. J Phys Oceanogr 41. https://doi.org/10.1175/JPO-D-11-03.1.

152. Slater DA, Goldberg DN, Nienow PW, Cowton TR. Scalings for submarine melting at tidewater glaciers from buoyant plume theory. J Phys Oceanogr. 2016;46:1839-55. https://doi.org/10.1175/ JPO-D-15-0132.1.

153. Böning CW, Behrens E, Biastoch A, et al. Emerging impact of Greenland meltwater on deepwater formation in the North Atlantic Ocean. Nat Geosci. 2016;9:523-7. https://doi.org/10.1038/ngeo2740.

154. Weijer W, Maltrud ME, Hecht MW, et al. Response of the Atlantic Ocean circulation to Greenland ice sheet melting in a strongly-eddying ocean model. Geophys Res Lett. 2012;39: L09606. https://doi.org/10.1029/2012GL051611.

155. de Jong MF, Bower AS, Furey HH. Two years of observations of warm-core anticyclones in the Labrador Sea and their seasonal cycle in heat and salt stratification. J Phys Oceanogr. 2013;44: 427-44. https://doi.org/10.1175/JPO-D-13-070.1.

156. Marshall DP, Ambaum MHP, Maddison JR, Munday DR, Novak L. Eddy saturation and frictional control of the Antarctic circumpolar current. Geophys Res Lett. 2017;44:286-92. https:// doi.org/10.1002/2016GL071702.

157. Marshall DP, Maddison JR, Berloff PS. A framework for parameterizing eddy potential vorticity fluxes. J Phys Oceanogr. 2012;42:539-57. https://doi.org/10.1175/JPO-D-11-048.1.

158. Mak J, Maddison JR, Marshall DP, Munday DR. Implementation of a geometrically informed and energetically constrained mesoscale eddy parameterization in an ocean circulation model. J Phys Oceanogr. 2018;48:2363-82. https://doi.org/10.1175/JPO-D-180017.1.

159. Nadiga BT. Orientation of eddy fluxes in geostrophic turbulence. Philos Trans R Soc A Math Phys Eng Sci. 2008;366:2489-508. https://doi.org/10.1098/rsta.2008.0058.

160. Grooms I, Majda AJ. Efficient stochastic superparameterization for geophysical turbulence. Proc Natl Acad Sci U S A. 2013;110:4464-9.

161. Zanna L, Porta Mana P, Anstey J, et al. Scale-aware deterministic and stochastic parametrizations of eddy-mean flow interaction. Ocean Model. 2017;111:66-80. https://doi.org/10.1016/j. ocemod.2017.01.004.

162. Resseguier V, Pan W, Fox-Kemper B. Data-driven versus selfsimilar parameterizations for stochastic advection by Lie transport and location uncertainty. Nonlinear Process Geophys. 2020;27: 209-34. https://doi.org/10.5194/npg-27-209-2020.

163. Zanna L, Bachman S, Jansen M. Energizing turbulence closures in ocean models. CLIVAR Exch CLIVAR Var. 2020;18:3-8. https:// doi.org/10.5065/g8w0-fy32.

164. Porta Mana P, Zanna L. Toward a stochastic parameterization of ocean mesoscale eddies. Ocean Model. 2014;79:1-20. https://doi. org/10.1016/j.ocemod.2014.04.002.

165. Anstey JA, Zanna L. A deformation-based parametrization of ocean mesoscale eddy Reynolds stresses. Ocean Model. 2017;112:99-111.

166. Bachman SD, Anstey JA, Zanna L. The relationship between a deformation-based eddy parameterization and the lans- $\alpha$ turbulence model. Ocean Model. 2018;126:56-62.

167. Jansen MF, Held IM. Parameterizing subgrid-scale eddy effects using energetically consistent backscatter. Ocean Model. 2014;80: 36- 48 .

168. Jansen MF, Held IM, Adcroft A, Hallberg R. Energy budgetbased backscatter in an eddy permitting primitive equation model. Ocean Model. 2015;94:15-26.

169. Bachman SD. The GM+E closure: a framework for coupling backscatter with the Gent and McWilliams parameterization. Ocean Model. 2019;136:85-106. https://doi.org/10.1016/j. ocemod.2019.02.006.

170. Jansen MF, Adcroft A, Khani S, Kong H. Toward an energetically consistent, resolution aware parameterization of ocean mesoscale eddies. J Adv Model Earth Syst. 2019;11:2844-60. https://doi. org/10.1029/2019MS001750.

171. Juricke S, Danilov S, Koldunov N, et al. Ocean kinetic energy backscatter parametrization on unstructured grids: impact on global eddy-permitting simulations. J Adv Model Earth Syst. 2020;12: e2019MS001855. https://doi.org/10.1029/2019MS001855.

172. Renault L, McWilliams JC, Gula J. Dampening of submesoscale currents by air-sea stress coupling in the Californian upwelling system. Sci Rep. 2018;8:13388. https://doi.org/10.1038/s41598018-31602-3.

173. Haza AC, Özgökmen TM, Hogan P. Impact of submesoscales on surface material distribution in a gulf of Mexico mesoscale eddy. Ocean Model. 2016;107:28-47. https://doi.org/10.1016/j.ocemod. 2016.10.002.

174. Freilich MA, Mahadevan A. Decomposition of vertical velocity for nutrient transport in the upper ocean. J Phys Oceanogr. 2019;49:1561-75. https://doi.org/10.1175/JPO-D-19-0002.1. 
175. Chen Q, Ringler T, Gent PR. Extending a potential vorticity transport eddy closure to include a spatially-varying coefficient. Comput Math Appl. 2016;71:2206-17. https://doi.org/10.1016/j. camwa.2015.12.041

176. Maulik R, San O, Rasheed A, Vedula P. Subgrid modelling for two-dimensional turbulence using neural networks. J Fluid Mech. 2019;858:122-44. https://doi.org/10.1017/jfm.2018.770.

177. Pearson B, Fox-Kemper B. Log-normal turbulence dissipation in global ocean models. Phys Rev Lett. 2018;120. https://oi.org/10. 1103/PhysRevLett.120.094501.

178. Soufflet Y, Marchesiello P, Lemarié F, et al. On effective resolution in ocean models. Ocean Model. 2016;98:36-50.

179. Stewart KD, Hogg AM, Griffies SM, et al. Vertical resolution of baroclinic modes in global ocean models. Ocean Model. 2017;113:50-65. https://doi.org/10.1016/J.OCEMOD.2017.03. 012 .

180. Roberts M (2017) MOHC HadGEM3-GC31-HM model output prepared for CMIP6 HighResMIP, Earth System Grid Federation. https://doi.org/10.22033/ESGF/CMIP6.446.

181. Roberts M (2017) MOHC HadGEM3-GC31-LL model output prepared for CMIP6 HighResMIP, Earth System Grid Federation. https://doi.org/10.22033/ESGF/CMIP6.1901.

182. Roberts M (2018) MOHC HadGEM3-GC31-HH model output prepared for CMIP6 HighResMIP, Earth System Grid Federation. https://doi.org/10.22033/ESGF/CMIP6.445.

183. Roberts CD, Senan R, Molteni F, et al (2017) ECMWF ECMWFIFS-LR model output prepared for CMIP6 HighResMIP, Earth System Grid Federation. https://doi.org/10.22033/ESGF/CMIP6. 2463.

184. Roberts CD, Senan R, Molteni F, et al (2017) ECMWF ECMWFIFS-HR model output prepared for CMIP6 HighResMIP, Earth System Grid Federation. https://doi.org/10.22033/ESGF/CMIP6. 2461.

185. Voldoire A (2019) CNRM-CERFACS CNRM-CM6-1 model output prepared for CMIP6 HighResMIP, Earth System Grid Federation. https://doi.org/10.22033/ESGF/CMIP6.1925.
186. Voldoire A (2019) CNRM-CERFACS CNRM-CM6-1-HR model output prepared for CMIP6 HighResMIP, Earth System Grid Federation. https://doi.org/10.22033/ESGF/CMIP6.1387.

187. Scoccimarro E, Bellucci A, Peano D (2017) CMCC CMCC-CM2HR4 model output prepared for CMIP6 HighResMIP, Earth System Grid Federation. https://doi.org/10.22033/ESGF/CMIP6. 1359.

188. Scoccimarro E, Bellucci A, Peano D (2017) CMCC CMCC-CM2VHR4 model output prepared for CMIP6 HighResMIP, Earth System Grid Federation. https://doi.org/10.22033/ESGF/CMIP6. 1367.

189. EC-Earth (2018) EC-Earth-Consortium EC-Earth3P-HR model output prepared for CMIP6 HighResMIP, Earth System Grid Federation. https://doi.org/10.22033/ESGF/CMIP6.2323.

190. EC-Earth (2019) EC-Earth-Consortium EC-Earth3P model output prepared for CMIP6 HighResMIP, Earth System Grid Federation. https://doi.org/10.22033/ESGF/CMIP6.2322.

191. von Storch J-S, Putrasahan D, Lohmann K, et al (2017) MPI-M MPIESM1.2-HR model output prepared for CMIP6 HighResMIP, Earth System Grid Federation. https://doi.org/10.22033/ESGF/ CMIP6.762.

192. von Storch J-S, Putrasahan D, Lohmann K, et al (2017) MPI-M MPI-ESM1.2-XR model output prepared for CMIP6 HighResMIP, Earth System Grid Federation. https://doi.org/10. 22033/ESGF/CMIP6.10290.

193. Gent, Peter (2020). NCAR CESM1-CAM5-SE-LR model output prepared for CMIP6 HighResMIP, Earth System Grid Federation. https://doi.org/10.22033/ESGF/CMIP6.14262.

194. Gent, Peter (2020). NCAR CESM1-CAM5-SE-HR model output prepared for CMIP6 HighResMIP, Earth System Grid Federation. https://doi.org/10.22033/ESGF/CMIP6.14220.

195. Van Roekel, Luke. (2020). E3SM - Drake Passage Transport, 26.5 AMOC, Northward Heat Transport at $26.5 \mathrm{~N}$, from Hewitt et al 2020 [Data set]. Zenodo. https://doi.org/10.5281/zenodo.4064616.

Publisher's Note Springer Nature remains neutral with regard to jurisdictional claims in published maps and institutional affiliations.

\section{Affiliations}

\section{Helene T. Hewitt ${ }^{1}$ iD $\cdot$ Malcolm Roberts ${ }^{1} \cdot$ Pierre Mathiot $^{1} \cdot$ Arne Biastoch $^{2} \cdot$ Ed Blockley $^{1} \cdot$ Eric P. Chassignet $^{3}$. Baylor Fox-Kemper ${ }^{4}$ - Pat Hyder ${ }^{1}$ - David P. Marshall ${ }^{5}$. Ekaterina Popova ${ }^{6}$ • Anne-Marie Treguier ${ }^{7}$. Laure Zanna ${ }^{8}$. Andrew Yool ${ }^{6}$. Yongqiang Yu ${ }^{9,10}$. Rebecca Beadling ${ }^{11}$. Mike Bell ${ }^{1}$. Till Kuhlbrodt $^{12} \cdot$ Thomas Arsouze $^{13}$. Alessio Bellucci ${ }^{14}$. Fred Castruccio ${ }^{15,16}$. Bolan Gan ${ }^{17,16} \cdot$ Dian Putrasahan $^{18} \cdot$ Christopher D. Roberts $^{19}$. Luke Van Roekel ${ }^{20}$ - Qiuying Zhang ${ }^{21,16}$}

1 Met Office Hadley Centre, FitzRoy Road, Exeter, UK

2 GEOMAR Helmholtz Centre for Ocean Research Kiel, Kiel University, Kiel, Germany

3 Center for Ocean-Atmospheric Prediction Studies, Florida State University, Tallahassee, FL, USA

4 Earth, Environmental, and Planetary Sciences, Brown University, Providence, RI, USA

5 Department of Physics, University of Oxford, Oxford, UK

6 National Oceanography Centre, Southampton, UK

7 CNRS, IRD, Ifremer, Laboratoire d'Océanographie Physique et Spatiale (LOPS), IUEM, Univ. Brest, Brest, France
8 Courant Institute, New York University, New York, NY, USA

9 LASG, Institute of Atmospheric Physics, Chinese Academy of Sciences, Beijing 10029, China

10 University of Chinese Academy of Sciences, Beijing 100039, China

11 Department of Geosciences, The University of Arizona, Tucson, AZ, USA

12 National Centre for Atmospheric Science, Department of Meteorology, University of Reading, Reading, UK

13 Barcelona Supercomputing Center - Centro Nacional de Supercomputación (BSC), Barcelona, Spain 
14 Fondazione Centro Euro-Mediterraneo sui Cambiamenti Climatici (CMCC), Bologna, Italy

15 National Center for Atmospheric Research (NCAR), Boulder, CO, USA

16 International Laboratory for High Resolution Earth System Prediction (iHESP), College Station, TX, USA

17 Qingdao National Laboratory for Marine Science (QNLM), Qingdao, China
18 Max Planck Institute for Meteorology, Hamburg, Germany

19 European Centre for Medium-Range Weather Forecasts (ECMWF), Reading, UK

20 T-3 Solid Mechanics and Fluid Dynamics, Los Alamos National Laboratory, Los Alamos, NM, USA

21 Texas A\&M University (TAMU), College Station, TX, USA 